\title{
Membaca Pemikiran Kuntowijoyo dalam Hubungan Ilmu dan Agama Perspektif Islam
}

\author{
Siti Qurrotul A'yuni' ${ }^{1}$, Radia Hijrawan ${ }^{1}$ \\ ${ }^{1}$ Universitas Islam Negeri Sunan Kalijaga, Yogyakarta \\ *Corresponding email: sitiqurrotulayuni95@gmail.com
}

Naskah diterima: 27 April| disetujui: 28 Mei 2021 | diterbitkan: 1 Juli 2021

\begin{abstract}
This study examines the thoughts of Kuntowijoyo as a Muslim scholar who is very influential in Indonesian scientific disciplines. In his view, Indonesian Muslims have gone through stages of awareness. These stages are divided into three periods, namely: the period of myth, the period of ideology and the period of science.The mythical period where ancient people really believed in something mystical. Then the development of the era in the Ideological Period began to recognize scientific treasures so that some of these mystical beliefs could be proven by science. Meanwhile, humans are currently in the Period of Science, namely interpreting modern sciences. A detailed explanation related to the period was compiled based on several references obtained by the author in qualitative research methods and packaged in the Library Research. The author identifies through Kuntowijoyo's original work and explores other scientific studies related to his written thoughts, both in print and digital media. The results show the study of Islam as a science, the method of transcendental structuralism and the concept of prophetic social science according to Kuntowijoyo in an Islamic perspective.
\end{abstract}

Keywords: Science, Religion, Islamic Perspective, Kuntowijoyo's Thought

\begin{abstract}
Abstrak
Penelitian ini meninjau pemikiran Kuntowijoyo sebagai cendekiawan muslim yang sangat berpengaruh terhadap disiplin keilmuan Indonesia. Menurut pandangannya umat Islam Indonesia telah melalui tahapan-tahapan kesadaran. Tahapan tersebut terbagi menjadi tiga periode, yaitu periode mitos, periode ideologi, dan periode ilmu. Periode mitos di mana zaman dahulu orang-orang sangat percaya dengan sesuatu yang bersifat mistis. Kemudian berkembangnya zaman pada periode ideologi mulai mengenal khazanah keilmuan sehingga beberapa kepercayaan mistis tersebut bisa dibuktikan dengan keilmuan. Sedangkan saat ini manusia sudah berada pada periode ilmu yaitu menginterpretasikan ilmu-ilmu modern. Penjelasan mendetail terkait periode tersebut dihimpun berdasarkan beberapa referensi yang diperoleh penulis dalam metode penelitian kualitatif dan dikemas dalam library research. Penulis melakukan identifikasi melalui karya asli milik Kuntowijoyo dan menelusuri telaah keilmuan lain terkait pemikiran beliau yang sifatnya tertulis, baik dalam media cetak maupun digital. Hasilnya menunjukkan kajian tentang Islam sebagai Ilmu, metode strukturalisme transendental, serta konsep ilmu sosial profetik menurut Kuntowijoyo dalam perspektif Islam.
\end{abstract}

Kata Kunci: Ilmu, Agama, Perspektif Islam, Pemikiran Kuntowijoyo 


\section{Pendahuluan}

Kuntowijoyo dalam tulisannya yang berjudul "Islam sebagai Ilmu Epestimologi, Metodologi dan Etika" menyatakan bahwa seorang muslim hendaknya memandang hal nyata melalui kaca mata Islam dan eksistensi ilmu-ilmu yang bersentuhan dengan nilai-nilai kemanusiaan dalam Al-Qur'an. Antara kebenaran dan kemajuan sering dianggap sama. Sehingga manusia beranggapan bahwa kebenaran banyak dipengaruhi oleh kemajuan-kemajuan yang disaksikan. Adapun kebenaran bersifat tidak bertambah atau disebut juga non-culumative dan kemajuan itu cumulative (bertambah). Maknanya, tidak ada perkembangan pada kebenaran tersebut meskipun zaman dan waktu terus berkembang (Kuntowijoyo 2007:3-4).

Pandangan Kuntowijoyo pada umat Islam Indonesia telah melewati tahapan-tahapan sebuah kesadaran. Tahapan tersebut terbagi menjadi tiga periode, yaitu periode mitos, periode ideologi dan periode ilmu. Hal ini didasarkan pada sosiologi pengetahuan, yaitu dengan melihat wujud dari kesadaran masyarakat luas pada suatu zaman. Periode mitos, diartikan tatkala memperlihatkan kesadaran umat dalam tahapan mistis-religius, sehingga dasar pengetahuannya berupa mitos. Masyarakat pada saat itu sangat percaya dengan cerita-cerita mistis tradisional yang disampaikan melalui sastra lisan atau dari mulut ke mulut. Periode ideologi, diartikan bahwa khazanah pengetahuan Islam dipahami sebagai formulasi normatif yang kemudian menjadi sebuah ideologi lalu menjadi action. Hal ini diartikan bahwa pada masa itu orang-orang berpegang terhadap kaidah norma yang berlaku sampai menjadi sebuah pemikiran, kemudian puncaknya adalah membentuk perilaku manusia yang mulai berfikir, bukan lagi percaya seutuhnya pada sebuah cerita-cerita mitos. Masa ilmu merupakan proses pengalihan ilmu modern dengan diawali proses mengambil alih substansi dan metode sebelumnya hingga pada akhirnya dibenarkan oleh substansi Islam. Artinya, manusia dapat menyerap ilmu-ilmu modern yang mereka pelajari. Untuk memperoleh keabsahan terhadap keilmuan yang diperoleh tersebut, mereka menjadikan nilai-nilai dalam ajaran Islam sebagai tolak ukur suatu kebenaran (Kuntowijoyo 2017:36).

Kuntowijoyo menempatkan amar ma'ruf sebagai humanisasi, yang berarti menegakkan kebenaran adalah bentuk menumbuhkan rasa kemanusiaan. Kemudian nahi munkar atau melarang berbuat kejelekan sebagai suatu liberalisasi dan tu'minu billah sebagai trasnsendensi dalam surat Ali Immron ayat 110, bukan berarti bahwa dirinya sedang berlagak menjadi sosok ahli tafsir (Kuntowijoyo 2008:229). Gagasan mengenai Islam sebagai ilmu pada dasarnya merupakan rute yang tidak condong pada sebelah pihak. Pemikiran tersebut lahir berdasarkan identifikasi mendalam yang berbasis epistemologi beliau yang matang sehingga menghasilkan ide cemerlang menjadi produk keilmuan pada zamannya.

Maka dari itu tulisan ini menjadi penting karena mengkaji tentang keilmuan yang dimiliki oleh cendekiawan muslim Indonesia. Melakukan analisis pemikiran Kuntowijoyo sebagai sosok yang berpengaruh dalam kajian keilmuan agama Islam. Mengidentifikasi karyanya juga karya lain yang membahas pemikirannya sehingga merubah paradigma berfikir yang sebelumnya, di mana sering dikenal "Islamisai pengetahuan" yang seharusnya menjadi "Pengetahuan Islam". Oleh karena itu, diharapkan hasil penulisan ini mampu memberikan sumbangsih pemahaman tentang Islam sebagai ilmu bagi pendidikan islam di Indonesia yang sifatnya dinamis.

Penulisan dalam karya ilmiah ini berdasarkan metode kualitatif yang menggunakan analisis data deskriptif. Reverensi yang diperoleh dikelompokkan menjadi dua golongan, yaitu sumber data yang bersifat primer dan sumber data yang bersifat sekunder. Sumber data primer dikutip dari buku asli karya Kuntowijoyo, sedangkan sumber data sekunder berasal dari buku-buku, laporan, artikel 
atau kajian ilmiah tertulis milik akademisi atau penelitian-penelitian yang telah dilakukan sebelumnya. Hal tersebut tidak berbatas hanya berdasarkan media cetak saja, melainkan juga berbentuk digital. Oleh karena itu, artikel ilmiah ini termasuk dalam kategori penelitian lybrary research atau penelitian kepustakaan.

\section{Biografi Kuntowijoyo}

Kuntowijoyo lahir di Saden, selatan Bantul, Daerah Istimewa Yogyakarta, pada tanggal 18 September 1943. Beliau merupakan anak dari pasangan H. Abdul Wahid Sosromartojo dan Hj. Warasti. Masa kecil Kuntowijoyo ada di bawah asuhan keluarga Jawa yang taat beragama Islam. Kuntowijoyo juga pernah diasuh oleh kakeknya di desa Ngawonggo yang memiliki bakat seni dan budaya Jawa, sehingga menurunkan darah seni dan intelektual kepada cucunya. Beliau dikenal sebagai sastrawan, budayawan, dan sejarawan. Begitu banyak karya-karyanya yang berkecimpung dalam bidang-bidang tersebut (Suryo 2005:1-5) .

Sejak kecil Kuntowijoyo dibesarkan dengan penanaman nilai-nilai keagamaan. Semasa kecilnya aktif mengikuti kegiatan di masjid. Pagi hari menempuh pendidikan di Sekolah Rakyat Negeri, lalu setelah dzuhur hingga menjelang waktu ashar ia bergegas menuju Surau/Langgar guna mempelajari agama. Sedangkan menjelang malam usai maghrib menuju isya' beliau mengaji. Saat di Surau, beliau juga aktif belajar menulis puisi. Semua aktivitas tersebut dipelajari dari gurunya M. Yusmanan dan M. Saribi Arifin. Bakat menulisnya sudah terasah sejak usia dini. Perhatian dan antusiasme belajar tinggi terhadap persoalan sejarah juga mulai tampak sejak kecil. Saat itu beliau sangat terkesima dengan guru mengajinya Ustadz Mustajab yang mahir mengisahkan tentang tarikh atau sejarah Islam. Selain senang berdeklamasi, mengaji, dan mendongeng, beliau juga sangat gemar membaca buku di perpustakaan kota kecamatan. Buku-buku yang dibacanya pun banyak yang ditulis oleh budayawan terkemuka dan tokoh-tokoh sejarah. Tidak heran jika hal tersebut berpengaruh besar dalam perjalanan karirnya ketika dewasa. Perhatian dan minatnya pada sejarawan serta kesenangannya membaca karya budayawan membuat beliau melahirkan karya yang serupa (Abidin 2016:65-70).

Djoko Suryo memaparkan (Suryo 2005) kecintaan Kuntowijoyo mempelajari sejarah bertepatan dengan puncaknya masa perkembangan studi sejarah kritis (critical historical studies) atau studi sejarah modern (modern historical studies), studi sejarah kritis dan analitis penggarapan obyek kajian sejarah. Sehingga, dari sinilah beliau mulai mengenal berbagai macam pendekatan-pendekatan ilmu sosial (sosial scientific approach). Bukan hanya sebagai sejarawan, Kuntowijoyo juga termasuk salah satu penulis yang produktif. Khusus dalam menulis cerpen dan novel, beliau selalu aktif untuk menghasilkan karya dan ide-ide mutakhir. Karya dan gasan-gagasan beliau dikenal luas melalui buku yang ditulis. Hasil karya Kuntowijoyo juga bervariasi, sehingga beliau bisa dikategorikan sebagai sastrawan karena sampai akhir hayatnya beliau tetap menulis. Kuntowijoyo juga masuk dalam kategori sejarawan dan budayawan, hal itu karena analisis pemikiran yang dituliskan menjadi disiplin ilmu sejarah dan telah banyak diterbitkan menjadi buku-buku. Riwayat pendidikan juga dapat menjadi bukti bahwa beliau patut menyandang julukan sejarawan. Kategori agamawan juga cocok disandang oleh beliau, sebab pada masanya amat giat menguraikan, membedah, lalu menuliskan tentang kajian keislaman, oleh karena itu karya-karya yang dihasilkan sangat mewarnai khazanah keilmuan khususnya di Indonesia (Anon n.d.). 
Pada tahun 1990-an Kuntowijoyo mengidap penyakit langka di Indonesia. Beliau divonis radang selaput otak atau meningo enshrphsilitis. Oleh karena itu, kemampuan otak untuk menggerakkan anggota tubuhnya terganggu. Kesulitan yang dialaminya menjadikan Kuntowijoyo semakin bersemangat menghabiskan waktunya untuk menulis. Akhirnya pada tahun 1999, SEA Write Award dari Thailand (Penghargaan Penulis Asia Tenggara) salah satu sastra bergengsi di Asia Tenggara memberikan sebuah penghargaan. Banyak kalangan yang juga memberikan pujian serta mengatakan bahwa tulisan Kuntowijoyo pada saat sakit lebih jernih dan mengagumkan (Fahmi 2005:37).

\section{Kajian Pemikiran Islam sebagai Ilmu Menurut Kuntowijoyo}

Ilmu secara etimologis ialah "scientia" kata ini berasal dari bahasa latin yang artinya (1) pengetahuan tentang; (2) pengetahuan yang mendalam, ilmu, mengerti, ahli, mengetahui, faham yang sebenarnya (Prent dkk, 1996). Ilmu dalam makna denotatif merujuk pada "pengetahuan", "tubuh pengetahuan yang terorganisir", "studi sistematis", dan "pengetahuan teoritis" (The Liang Gie dalam Tim Dosen Filsafat Ilmu UGM, 1996). Makna tersebut berpatokan pada ranah yang amat luas pengertiannya, entah dari segi "pengetahuan" selayaknya yang telah manusia miliki, ataupun "pengetahuan ilmiah" yang sistematis tertata lalu melalui proses khusus ditingkatkan.

Menurut Daoed Joesoef, pengertian ilmu mengacu pada tiga hal, yaitu produk-produk, proses, dan masyarakat (Mustansyir, Rizal \& Munir, Misnal, 2013). Makna ilmu menurut Jujun S. Suriasumantri pada dasarnya memiliki tiga landasan, yaitu ontologis, epistimologis, dan aksiologis. Ontologis membahas mengenai sesuatu yang dipahami atau berteori tentang "ada". Patokan ontologis dari ilmu berkaitan dengan materi yang menjadi objek menyelidiki ilmu. Epistemologis/ teori adalah pengetahuan yang membahas secara mendalam mengenai usaha untuk memperoleh pengetahuan, sehingga ilmu ialah pengetahuan yang diperoleh melalui proses tertentu yang disebut metode keilmuan. Dasar aksiologis merupakan ilmu yang membahas mengenai manfaat yang diperoleh manusia dari pengetahuan yang didapatkan (Azizah and Newton 2018:151-56). Berdasarkan pemaparan tersebut dapat di tarik kesimpulan bahwa ketiga aspek ilmu merupakan pengetahuan yang dimiliki oleh manusia sehingga dengan memahami ketiganya dapat memberikan manfaat bagi setiap manusia.

Aspek penting berikutnya yang ada pada masyarakat Indonesia adalah soal agama. Agama merupakan ajaran yang diturunkan Tuhan sebagai pedoman hidup bagi umatnya (Agus 2006:33). Agama juga disebut sebagai suatu ciri kehidupan sosial yang universal, artinya bahwa setiap semua masyarakat memiliki cara berpikir dan pola-pola berperilaku sehingga dapat disebut "Agama" yang berupa simbol-simbol, citra, kepercayaan dan nilai-nilai spesifik. Sehingga manusia dapat menginterpretasikan eksistensi yang di dalamnya mengandung komponen ritualitas (Kahmad 2009:33). Menurut ajaran Islam, agama adalah risalah yang disampaikan Allah melalui para malaikat yang kemudian disampaikan kepada para nabi untuk diajarkan kepada manusia di muka bumi. Agama dijadikan pandangan dan kesadaran untuk menjalani kehidupan, menekankan kepada ketentraman hati, keselarasan dan keseimbangan jiwa, disertai dengan sikap menerima terhadap apa yang terjadi. Kerangka berfikir dan pola hidup yang demikian mencerminkan bahwa apa yang menjadi tujuan adalah ketenangan batin, sebab agama adalah pelindung hati, batin, dan jiwa seseorang. 
Oleh karena itu, Kuntowijoyo seorang pemikir muslim ulung konsep keilmuannya tidak hanya di bidang keagamaan, bahkan politik, sosial, sastra, dan budaya. Persoalan yang dihadapi ialah bagaimana cara menyosialisasikan suatu paradigma baru dalam ilmu. Kuntowijoyo tidak lagi menggunakan paradigma Islamisasi Pengetahuan, namun dirinya ingin mensuport gerakan intelektual umat sekarang ini melangkah lebih jauh, dan mengganti "Islamisasi Pengetahuan" menjadi "Pengilmuan Islam".

Sebab Islam sebagai ilmu merupakan reaksi akademik dari islamisasi ilmu, apalagi secara terang-terangan Kuntowijoyo membantah Islamisasi ilmu dan berusaha menggantikannya dengan Islam sebagai Ilmu. Ia mengatakan bahwa ilmu berarti gerakan intelektual. Sehingga Islam harus melangkah menuju “pengilmuan Islam”. Sebagai umat muslim hendaknya meninggalkan "Islamisasi pengetahuan", kiprah intelektual yang lahir menjelang tahun 1980-an berupa gerakan dari konteks ke teks (konteks $\rightarrow$ teks). Sementara itu "pengilmuan islam" bergerak kearah yang berlawanan, yaitu dari teks menuju konteks (teks $\rightarrow$ konteks) (Kuntowijoyo 2007:1). Berdasarkan hal tersebut, pada era 80an pemikiran umat islam dalam memahami kajian keilmuan banyak dipengaruhi oleh konteks atau sosial dan ekologi yang berkembang pada saat itu, kemudian mengaitkan dengan teks. Sedangkan yang seharusnya dilakukan oleh umat muslim ialah mempelajari dan memahami teks terlebih dahulu, lalu kemudian mengaitkan dengan konteks yang ada. Di mana teks yang dimaksudkan dalam hal ini ialah bersumber kepada kitab suci umat Islam.

Merenungkan beberapa permasalahan manusia modern menjadi sangat penting untuk diperbincangkan, pasalnya saat ini manusia menghadapi berbagai macam problematika yang benarbenar membutuhkan solusi cepat. Terkadang manusia merasa berada pada posisi yang penuh persoalan dalam dunia modern, hal tersebut menimbulkan kemajuan dalam berpikir (Kuntowijoyo 2007:112). Dibalik kemajuan ilmu dan teknologi, dunia modern manusia semakin cerdas, mereka dapat membangun sebuah peradaban, mengorganisasikan ekonomi, menata struktur politik dan lain sebagainya. Manusia mampu menciptakan alat industri yang mempermudah pekerjaan mereka, namun hal itu malah menjadikan manusia sebagai operator saja, sehingga menjadikan manusia diperbudak dengan ciptaannya sendiri.

Paradigma pemikiran orang-orang barat saat itu hanya terpusat pada kajian terhadap manusia dan alam, mereka mengabaikan eksistensi wahyu Tuhan. Menurut pemikiran orang-orang barat, wahyu dianggap tidak mampu mengatasi permasalahan modern dan menemukan jalan buntu, bahkan tidak dapat berkontribusi pada lahirnya dehumanisasi manusia modern. Untuk menciptakan pembebasan mereka harus melepaskan belenggu keagamaan (Abidin 2016:112). Waktu itu mereka benar-benar percaya dan terkungkung mitologi paham dewa-dewa. Sehingga manusia tidak bisa menentukan keinginannya sendiri. Oleh karena itu, muncullah istilah sekularisme. Umat Nasrani percaya bahwa manusia adalah makhluk yang pendosa, sehingga membutuhkan penebus dosa untuk menghapus segala macam dosa yang diperbuat.

Islam telah mendeskripsikan dalam kitab suci surat Al-Baqarah ayat 30: "Ingatlah ketika Tuhanmu berfirman kepada para Malaikat; Sesungguhnya aku hendak menjadikan seseorang khalifah di muka bumi. Mereka berkata; Mengapa engkau hendak menjadikan khalifah di muka bumi, padahal ia akan membuat kerusakan padanya dan menumpahkan darah, padahal kami senantiasa bertasbih dengan memuji Engkau dan mensucikan Engkau. Tuhan berfirman; Sesungguhnya aku mengetahui apa yang tidak kamu ketahui." (Zulhelmi 2018:37) Berdasarkan penafsiran dari ayat tersebut Islam hadir membawa prinsip yang berbeda. Islam datang dengan mengangkat derajat manusia, 
menjadikannya pemimpin di muka bumi khalifah fil ard, menjadikan manusia sebagai wakil-wakil Allah, diberi kebebasan dalam mengatur dan mengelola ciptaan Allah di muka bumi. Tetapi tidak kemudian melupakan esensi diri bahwa sepatutnya manusia harus mengabdikan dirinya kepada Tuhan. Dalam Islam manusia di bebaskan untuk melakukan sesuatu, namun tetap harus berpasrah diri terhadap Tuhan.

Islam datang dengan mengubah asumsi tersebut secara keseluruhan, hal itu dijelaskan oleh Kuntowijoyo. Dalam Islam, manusia digambarkan sebagai makhluk rendah dan cuek, umat Kristen dipandang sebagai pendosa abadi, didekonstruksi sedemikian tinggi hingga mencapai tingkatan yang sangat bermartabat sebagai perwakilan Tuhan. Kedudukan manusia terangkat begitu tinggi hingga sampai pada derajat kemuliaan. Penekanan martabat manusia inilah yang dalam konsepsi Islam sangat berpengaruh. Jika dipersingkat, Islam meninggikan kedudukan manusia di muka bumi sebagai wakil Tuhan pada derajat yang tinggi. Namun agar sampai pada kualitas tersebut, manusia diwajibkan selalu mentaati-Nya. Sehingga manusia diberi peluang yang sama dan potensi yang berbeda oleh Tuhan untuk selalu mengembangkan dirinya (Kuntowijoyo 2007:112-118).

Perbedaan melahirkan pemikiran yang berbeda antara perkembangan ilmu di Barat dan Islam. Pada gilirannya ilmu integralistik (satunya akal dan wahyu) akan berkembang menjadi integralisme (satunya manusia dan agama) melawan kecenderungan sekularisme dunia modern dan pasca modern (Kuntowijoyo 2007:59).

PARADIGMA ISLAM:

IImu Barat (Modern) dan IImu Islam (Pascamodern)

\begin{tabular}{|c|c|c|c|c|c|}
\hline & PERIODE & SUMBER & ETIKA & $\begin{array}{c}\text { PROSES } \\
\text { SEJARAH }\end{array}$ & ILMU \\
\hline BARAT & Modern & Akal & Humanisme & Diferensiasi & $\begin{array}{c}\text { Sekular, } \\
\text { Otonom }\end{array}$ \\
\hline ISLAM & $\begin{array}{c}\text { Pasca- } \\
\text { modern }\end{array}$ & Wahyu Akal & $\begin{array}{c}\text { Humanisme- } \\
\text { Teosentris }\end{array}$ & $\begin{array}{c}\text { Dediferensias } \\
\mathrm{i}\end{array}$ & Integralistik \\
\hline
\end{tabular}

\section{Metode Struktualisme Transendental Kuntowijoyo}

Muhammad Zainal Abidin menjelaskan bahwa terdapat kisah sosio-historis masyarakat Arab pada proses panjang ketika Al-Qur'an diturunkan dengan keadaan masyarakat saat ini. Dulunya bangsa Arab adalah masyarakat yang pra-industrial atau dikenal pula sebagai masyarakat kesukuan (tribal society), dan juga disebut sebagai masyarakat homogen. Sedangkan masyarakat masa kini adalah masyarakat industrial, masyarakat kenegaraan, dan masyarakat heterogen. Kuntowijoyo memastikan penggunaan strukturalisme transendental sebagai metode dan tidak memilih hermeneutika yang umumnya lazim digunakan dalam memahami teks kitab suci (Abidin 2016:134). Dikuatkan dengan pernyataan Kutowijoyo dalam karyanya yang memaparkan bahwa, yang dibutuhkan umat saat ini bukan hanya sekadar pemahaman pada teks, melainkan juga bagaimana agar dengan teks tersebut dilakukan sebuah proses transformasi umat. Artinya apa yang diperoleh manusia melalui teks tidak serta merta ditelan tanpa melalui proses berfikir dan mengklarifikasi (Kuntowijoyo 2007:31). 
Menurut Michael Lane, dalam Introduction to Stucturalizm yang direduksi dalam buku Kuntowijoyo. Strukturalisme memiliki empat ciri. Pertama, memperhatikan secara menyeluruh atau dengan totalitas. Memahami unsur-unsur yang ada melalui keterkaitan (interconnectedness). Artinya, memberikan perhatian secara menyeluruh dan keseluruhan dengan sangat detail. Kedua, strukturalisme tidak memandang struktur di permukaan, melainkan dibagian bawah atau di balik kenyataan empiris. Sesuatu yang berada di permukaan adalah gambaran dari struktur bawah (deep structure), menyelam ke dasar lagi akan menemukan kekuatan yang membentuk struktur (innate structuring capacity). Maknanya lebih memandang ke dalam sebuah struktur, bukan dilihat dari apa yang tampak di permukaan saja, karena sesuatu yang tampak di permukaan sejatinya berkat pengaruh yang ada di dalam. Ketiga, tingkatan pengalaman atau empirisme yang berkaitan antar unsur bisa berupa binary opposition atau berarti ada dua hal yang berselisih. Keempat, strukturalisme menitik beratkan terhadap unsur yang tersinkron atau bisa juga disebut dengan singkronis, bukan unsur yang tidak tersingkron atau disebut diakronis. Komponen-komponen tersebut berada pada waktu yang bersamaan, dan bukan perkembangan yang terjadi antar suatu masa, diakronis, atau historis (Kuntowijoyo 2001:6).

Interconnectedness hubungannya dalam Islam pada kandungan Al-Qur'an merupakan komponen yang saling berkaitan. Dapat dicontohkan seperti keterkaitan antara puasa dan zakat yang merupakan gambaran atas hubungan garis lurus ke-atas seorang insan dengan Tuhan, kemudian hubungan garis sejajar antar manusia yaitu salat dengan solidaritas sosial terhadap kemiskinan. Begitupun keterkaitan antara keimanan dan perbuatan baik atau amal shaleh. Logical consequences hubungannya juga bisa dimaknai sebagai bagian dari suatu unsur. Keseluruhan rukun Islam (shalat, zakat, puasa, dan haji) ialah resultan dari dua kalimat syahadat. Mengeluarkan atau menerima zakat merupakan akibat logis usai berpuasa di mana seseorang merasakan arti rasa lapar dan dahaga (Kuntowijoyo 2001:8).

Ciri selanjtnya adalah innate structuring capacity. Tauhid dalam Islam atau mengetahui tentang hakikat ketuhanan mempunyai kekuatan membentuk struktur yang paling dalam. Pasalnya seseorang yang memikirkan siapa Tuhannya, mencari tahu tentang siapa Tuhannya merupakan hal penting membangun kepercayaan. Ciri berikutnya adalah deep structure, maknanya setelah mempelajari tentang ketuhanan, manusia menemukan ajaran dari ketuhanan itu sendiri, yaitu akidah, ibadah, akhlak, syariah, dan muamalah. Akan terlihat pembawaan dari seseorang baik shalatnya, puasanya, moral/etika, perilaku normatif, dan perilaku sehari-hari. Perilaku ini merupakan bentuk dari implikasi seseorang ketika mengenal ajaran Tuhan. Kemudian akidah, ibadah, akhlak, dan syariah yang bersifat immutable (tidak berubah) dari masa ke masa, maupun dari tempat ke tempat, sedangkan yang dapat berubah ialah perdagangan. Maka dari itu Kuntowijoyo mengungkapkan transformasi dalam muamalah ialah adanya bukti perubahan dalam Islam, bukan perubahan yang terjadi pada sektor lain (Kuntowijoyo 2001:8-9).

Ciri selanjutnya adalah binary opposition, pertentangan dua gejala baik menimbulkan keseimbangan berupa konflik antara musuh masing-masing maupun pasangan. Pertikaian tersebut dapat dicontohkan antara kepentingan Tuhan dan kepentingan makhluknya, pertikaian antara ruhani dengan jasmani, batiniyah dengan lahiriyah, pria dan wanita, alam dunia dengan alam akhirat, si pemberi zakat dengan penerima zakat, fakir miskin dengan si kaya, dan sebagainya yang menghasilkan perubahan dan mempengaruhi antara satu sama lain. Sementara itu, pertentangan antar struktur menghasilkan problematika. Misalnya pertentangan antara Tuhan berlawanan dengan setan, 
dzulumat (kegelapan) berlawanan dengan nur (cahaya), mukmin berlawanan dengan musyrik, saleh berlawanan dengan fasad, syukur berlawanan dengan kufur, ma'ruf berlawanan dengan munkar, surga berlawanan dengan neraka, kesabaran berlawanan dengan amarah, halal berlawanan dengan haram. Semua itu merupakan bagian dari konflik dan karena itulah manusia harus memilih salah satu (Kuntowijoyo 2018:8).

Selanjutnya Kuntowijoyo (Kuntowijoyo 2007:39) menjelaskan dengan mengambil kutipan milik Webster's New International Dictionary. Kata "melampaui" diartikan sebagai makna yang dimaksudkan pada pengertian strukturalisme transendental. Melampaui di sini merupakan cara menerapkan sistem pengetahuan (episteme) sosial yang lahir lima belas abad lalu. Terdapat space geografis, historis, dan sosial. Menurutnya banyak agamawan yang tidak mampu menerjemahkan fenomena sekarang. Akibatnya nepotisme, kolusi, dan monopoli melibatkan orang yang mempunyai kesalehan pada level tertinggi. Hal itu tetap dianggap melakukan amal saleh karena sumber yang digunakan adalah pengetahuan abad tengah Islam. Tidak sedikit agamawan yang gagal menemukan perbedaan antara gejala alamiah dengan gejala buatan manusia, seolah-olah menampakkan kesalehan pribadi padahal mereka gagal melihat kepentingan kesalehan publik.

Kuntowijoyo juga memaparkan bahwa masyarakat petani dan (peasent society) atau masyarakat pra industri umumnya sangat bergantung terhadap akhlak dan juga moral dari individu, sementara itu masyarakat yang sudah atau sedang bergerak pada bidang industri (industrial society) terletak pada akhlak/moral yang kolektif. Masyarakat di negara kita berprofesi sebagai petani sangat menggantungkan diri pada negaranya yang berperan sebagai pemegang kekuasaan. Hal ini dapat dipahami bahwa masyarakat industri berkebalikan, negaralah yang menggantungkan diri kepada masyarakatnya (Kuntowijoyo 2007:40). Berbicara mengenai strukturalisme transendental, menurut Kuntowijoyo akan digunakan terhadap tiga bidang keilmuan, yakni ilmu alam, ilmu kemanusiaan, dan ilmu agama. Salah satu masalah besar bagi Islam ialah tanpa harus menghilangkan jati diri sebagai agama yang kaffah namun tetap mengikuti perkembangan zaman dan perubahan suatu masa. Kuntowijoyo hendak memupuk kesadaran melalui strukturalisme transendental. Hal ini menandakan bahwa kualitas keislaman yang parsial ialah hasil dari sikap parsial juga dalam memandang Islam, artinya kurang bermaknanya sebuah ajaran pamungkas dalam kesempurnaan agama Islam. Sehingga akan semakin sulit untuk terealisasi harapan Islam menjadi rahmat.

Kuntowijoyo dalam karyanya yang berjudul Maklumat Sastra Profetik menjelaskan bahwa Islam transendensi berisi ajaran sufisme. Kandungan yang terdapat di dalam sufisme yaitu, seperti Khauf yang artinya penuh rasa takut, Raja' memiliki makna sangat berharap, Tawakkal berarti pasrah, Qana'ah berarti menerima pemberian Tuhan, Syukur, Ikhlas dan lain sebagainya. Hal ini membuktikan bahwa Islam transendensi yang berisi ajaran sufisme ini menuntun manusia untuk menyucikan akhlak, berfikir jernih, dan membersihkan jiwa untuk memperoleh ketentraman dan kebahagiaan. Kandungan-kandungan tersebut merupakan tema-tema dalam sastra transendental (Kuntowijoyo 2019:30). Di sisi lain Jean Piaget (Peaget, 1995) menyebutkan tiga ciri struktur, yaitu totalitas, transformasi, dan pengaturan diri. Oleh Kuntowijoyo ketiga struktur tersebut dijabarkan sebagai berikut.

a. Keseluruhan (wholenes), suatu kohersi (keterpaduan). Terdiri dari kumpulan unsur-unsur yang lepas bukanlah arti dari struktur. Hukum yang mengatur seluruh sistem membuat unsur-unsur dari struktur patuh dan tunduk. Hukum pengatur struktur tidak dapat disusutkan ke dalam penjumlahan dari hukum yang mengatur satu demi satu unsurnya. Komponen-komponen 
tersebut tidak berpijak dengan cara terpisah, melainkan menjadi milik sebuah struktur. Hal ini membuktikan bahwa struktur merupakan wadah yang mempersatukan unsur-unsur lepas sehingga terbentuk keseluruhan.

b. Perubahan Bentuk (transformation), struktur bersifat dinamis, oleh karenanya struktur pasti mengalami perubahan bentuk. Struktur mampu memperkaya diri dengan menambah variasi material baru. Misalnya bahasa, dapat menambah variasi ungkapan-ungkapannya tanpa harus keluar dari kaidahnya. Meskipun berada dalam satu hukum yang sama sebuah struktur juga bisa melakukan perubahan yang positif tanpa harus melanggar aturan.

c. Pengaturan Diri Sendiri (self-regulation). Unsur-unsur baru yang ditambahkan hendaknya tidak pernah berada di luar struktur, melainkan tetap memelihara struktur tersebut. Sebuah struktur memayungi diri sendiri dan megeksklusifkan diri dari kemungkinan pengaruh luar. Artinya mereka dapat menjadi tameng dan penghalang atas kontrol diri jika dirasa ada yang keluar maupun melanggar batas hukum dalam sebuah struktur.

Sebagai konsep akhir, Kuntowijoyo menarik benang merah bahwa dengan metode strukturalisme transendental dapat terlihat pada enam sisi, yaitu pertama, Islam merupakan sebuah struktur. Kedua, sebagai metode, strukturalisme transendental tersinkron dengan apa yang dibutuhkan Islam saat ini. Ketiga, Islam memiliki kapasitas untuk megubah dirinya sendiri (transformasi diri) tanpa kehilangan keutuhannya. Keempat, tugas utama Islam masa kini adalah menyadari adanya perubahan yang terjadi dilingkungannya, sehingga dapat beradaptasi terhadap muamalahnya. Kelima, cerminan Islam yang kaku, anti perubahan, dan kuno adalah kurang tepat. Keenam, menghilangkan kesan garang terhadap Islam dengan mengkaji masalah kontemporer dalam bidang kemanusiaan, sosial, seni, filsafat, dan tasawuf.

Upaya yang dilakukan Kuntowojoyo dalam mempengaruhi pengilmuan Islam adalah bahwa dirinya menawarkan dua tindakan yang harus dipilih, yaitu integralisasi dan objektifikasi. Integralisasi merupakan pengintegrasian banyaknya keilmuan yang dimiliki manusia dengan firman Allah (Al-Qur'an beserta pelaksanaannya dalam sunnah nabi). Sedangkan objektifikasi ialah mengabulkan pengilmuan Islam sebagai rahmat untuk semua orang (rahmatan lil'alamin). Maknanya manusia hidup di dunia telah dibekali akal pikiran sebagai senjata dan alat mengasah senjata itu berupa kedua pusaka yakni Al-Qur'an dan sunnah nabi, kemudian alat untuk menajamkan senjata tersebut dijadikan sebuah perlindungan diri bagi musuh, bukan untuk menyerang dengan brutal.

Buah pemikiran integralisasi yang disampaikan Kuntowijoyo bermula dari pandangan ditemukannya suatu perbedaan mendasar antara produk-produk peradaban Barat berupa ilmu-ilmu sekuler. Oleh Islam semangat ilmu-ilmu integralistik digadangkan. Perbedaan disiplin ilmu antara ilmu-ilmu sekuler dengan ilmu-ilmu integralistik tersebut mencakup berbagai bagian yang dapat diurutkan mulai dari proses lahirnya sebuah ilmu, yakni pada tempat bermula, produk keilmuan, serangkaian proses, dan tujuan ilmu, yang secara umum meliputi aspek-aspek ontologis, epistemologis, dan aksiologis. Kuntowijoyo memformulasikan secara sistematis proses dari tahapan rangkaian dari asal mula kelahiran ilmu-ilmu sekuler yang didominasi oleh keilmuan manusia modern sekarang. Langkah tersebut kemudian disusun oleh Kuntowijoyo seperti gambar berikut (Kuntowijoyo 2007).

\section{Filsafat $\rightarrow$ Antropesentrisme $\rightarrow$ Diferensiasi $\rightarrow$ Ilmu Sekuler}


Karen Amstrong dalam bukunya yang diterjemahkan oleh Zainul Am menjelaskan kemunculan ilmu sekuler di atas bahwa tahapan-tahapannya dijabarkan oleh Kuntowijoyo. Menurut pandangannya permulaan dari ilmu-ilmu sekuler merupakan proses modernisasi dalam filsafat. Filsafat Rasionalisme yang timbul pada abad ke-15/16 menolak Ketuhanan atau Teosentrisme pada abad pertengahan. Rasio (pikiran) manusia ditinggikan dalam menistakan firmam Tuhan. Mereka menganut paham reverensi utama dari suatu kebenaran ialah logika berfikir, dan bukan dari firman Rabb. Mereka masih mengakui eksistensi Tuhan, hanya saja dianggap pasif, tidak dapat membuat jalan hukum, dan dianggap bukan penguasa. Penyangkalan terhadap kuasa Ilahi yang selama berabadabad memasung kehidupan di dunia Barat berjalan seiring dengan menempatkan manusia sebagai pusat dari suatu kehidupan yang ditempuh. Langkah ini disebut Antroposentrisme. Kuntowijoyo menjabarkan terkait hal ini bahwa dalam rasionalisme manusia menduduki kediaman yang tinggi. Manusia menjadi senter keabsahan, kebijaksanaan, etika, dan pengetahuan. Pelaksana, pencipta, dan konsumen dari hasil produksinya adalah manusia itu sendiri. Selanjutnya kelanjutan dari pandangan antroposentrisme ini ialah manusia membuat dirinya sebagai "penentu" atas keseluruhan hidupnya sendiri, kemudian mengabaikan aspek dari luar yang terlibat di dalamnya campur tangan Ilahiyah. Untuk itu hadirlah diferensiasi atau sekat di antara Rabb yang memiliki makna ajaran agama suci dengan kehidupan manusia (Amstrong, 44)

Bahasa Kuntowijoyo yang menyatakan bahwa, kala manusia beranggapan bahwa sosoknya menjadi senter dalam kehidupan, akan muncullah diferensiasi (pemisah). Kebijaksanaan, attitude, dan kognitif bukan lagi berlandaskan firman Ilahi. Oleh karena itu aktifitas ekonomi, hukum, politik, dan ilmu menjadi persoalan mutlak yang dipisahkan dari religion. Kebenaran ilmu terletak pada ilmu itu sendiri (tidak pula diluarnya: kitab suci), yaitu korespondensi di dalam ilmu, antara partikelpartikel keilmuan dengan keseluruhan bidang ilmu. Ilmu itu sendiri hendaknya bersifat objektif, tidak ada kaitannya dengan moral, etika, dan kepentingan lain. Berbicara fakta lapangan seperti ini merupakan hal yang berbanding terbalik dari fenomena yang terjadi di Barat pada abad tengah. Masa abad pertengahan ilmu ditempatkan sebagai pendukung firman Tuhan berupa Alkitab. Jika terdapat suatu komoditas ilmu yang bersinggungan dengan keterangan dalam kitab suci, maka produk ilmu tersebut tidak diizinkan untuk disebarluaskan dan wajib dilakukan perbaikan. Kemudian pada abad modern, saat antroposentrisme menggantikan teosentrisme, ilmu menjelma menjadi otonom. Suara yang kerap kali digaungkan adalah ilmu untuk ilmu. Sejak saat itu lahirlah ilmu-ilmu sekuler.

\section{Konsep Ilmu Sosial Profetik dalam Pemikiran Kuntowijoyo}

Pembahasan pada ranah pengembangan ilmu-ilmu sosial atau pendidikan tinggi Islam perlu memanfaatkan transformasinya secara kelembagaan. Institut Agama Islam Negeri (IAIN) atau Sekolah Tinggi Agama Islam Negeri (STAIN) yang bertransformasi memiliki kedudukan yang setara dengan Universitas Islam Negeri (UIN). Walaupun terdapat banyak instansi, lembaga pendidikan tinggi, dan pendidikan non-UIN yang terbelit diskusi tentang Islam dan ilmu pengetahuan, secara tidak langsung UIN memperoleh amanat resmi dalam mengembangkan sejumlah disiplin keilmuan berbasis Islam sebagai ekspansi dari instruksi ketika menjadi STAIN/IAIN yang pada mulanya sebatas memperkaya keilmuan di bidang agama. Amanat tersebut sepantasnya dimandatkan, mengingat perubahan dari STAIN-IAIN ke UIN bukan hanya sekadar perubahan nama atau 
nomenklatur kelembagaan, tetapi pergantian yang harus dibarengi karakter dari sisi keilmuan yang ditegaskan supaya tampak perbedaanya (distinction), juga harus mempunyai keistimewaan dibandingkan dengan perguruan tinggi yang bersifat umum, hal tersebut yang menjadi poin penting pada perubahan ini (Bagir 2005:20).

Zainal Abini Bagir memaparkan bahwa arti yang terdapat pada kata integrasi ialah memadukan. Integrasi keilmuan yang dikembangkan oleh UIN merupakan usaha dalam memadu padankan antara Islam dengan ilmu pengetahuan. Kedua bagian semasa ini ditatap secara terpisah, bahkan dipandang memiliki kontradiksi. Integrasi ilmu dengan agama adalah tugas menantang karena membutuhkan landasan filsafat yang meliputi empat aspek penting dalam ilmu filsafat, yaitu aspek ontologi, epistemologi, aksiologi, dan metodologi. Integrasi ilmu dalam artinya bukanlah suatu pekerjaan yang remeh dalam menghakimi keabsahan agama dengan hasil dari penemuan ilmiah seperti yang terkandung dalam natural theology yang tumbuh pada ranah tokoh kepercayaan umat Nasrani. Sistem aksi tersebut juga bertumbuh pada kancah umat muslim yang dikenal dengan Islam untuk Disiplin Ilmu atau disingkat menjadi IDI, hal ini bertujuan untuk mengembangkan studi Islam (Islamic studies). Pada bahasan IDI, wahyu yang tertulis dalam Al-Qur'an terutama yang menyimpan intruksi ilmiah dikaji dengan memanfaatkan teori dan konsep sebelumnya telah dikembangkan lebih dulu oleh intelektual khususnya dari Barat (Bagir 2005:21).

Pada dasarnya melaksanakan tinjauan Islam memakai sistem IDI tidak dapat dianggap biasa saja sebab mengukuhkan strategi secara multidisipliner, yaitu Islam dan ilmu pengetahuan alam (natural science), ilmu pengetahuan sosial (social science), dan humaniora (humanity studies). Tanpa menegarkan tiga ranting keilmuan tersebut, wahyu-wahyu dalam Al-quran maupun hadis yang mengandung sinyal-sinyal ilmiah akan sukar dimengerti dan dijabarkan. Tinjauan pada Al-Qur'an dengan memanfaatkan pendekatan IDI pada dasarnya sudah membuahkan karya yang lumayan. Misalnya, buku Tafsir Salman: Tafsir Ilmiah atas Juz Amma, hasil dari kajian ilmuwan ITB Bandung yang akhir-akhir ini dilaunchingkan oleh Mizan. Namun hasil yang diperoleh dianggap belum memadai melalui ID. Jjika ingin menempatkan seperti semula kemakmuran pranata keilmuan Islam, agaknya hanya sekadar mengadakan "ayatisasi" atau dengan melabeli firman Al-Qur'an serta hadis terhadap penemuan dalam ilmu pengetahuan modern. Bahkan membantah pihak eksternal bagi deretan yang tidak terpuaskan oleh sistem kerja IDI yang mengganggap agaman Islam tidak dapat sejalan dengan ilmu pengetahuan modern yang berkembang (Arifin 2014:487).

Kuntowijoyo ialah salah satu cendekiawan muslim yang merasa tidak berkenan dengan desain dari cara kerja IDI. Menurutnya Al-Qur'an dijadikan acuan, asal-muasal atau sumber Islam yang sangat diktatorial, bersifat akurat dan hendaknya ditempatkan pada posisi terpusat dan awalan dalam memajukan denyut nadi umat muslim yang juga mencakup aspek pengetahuan. Lalu pemikiran apologetik lebih memposisikan Al-Qur'an pada urutan terakhir dalam tinjauan keilmuan atau sematamata menjadikannya diposisi objek legitimasi beragam bahan-bahan ilmu pengetahuan modern. Menurut Kuntowijoyo, pada dasarnya Al-Qur'an kaya akan bermacam-macam konsep dan deskripsi yang menyimpan nilai-nilai bersejarah dan analog. Di mana ketika diinvestigasi dan dieksplanasi jauh mendalam, akan berdampak atas metamorfosis yang searah dengan visi Al-Qur'an tersebut (Arifin 2014:488).

Kuntowijoyo memecah konsepsi di dalam Al-Qur'an menjadi dua kategori, yaitu konsep abstrak dan konsep konkret. Konsep seperti Allah, akhirat, malaikat, ma'ruf, dan munkar, menurutnya seperti gagasan yang acak tak beraturan. Artinya, konsep ini sangat sulit dirasionalkan atau 
dilogikakan. Hanya mengandalkan keimanan tinggi yang dapat membenarkan konsep abstrak. Selanjutnya ditunjukkan gambaran yang termasuk dalam kategori nyata seperti du'afa, fuqara', mustad'afin, zalimin, mustakbirin, aghniya', mufsidun. Konsep perhatian terhadap Al-Qur'an penting agar ditampakkan pada berbagai deskripsi yang mengandung nilai historis seperti cerita kebengisan Raja Firaun, kesabaran Nabi Ayyub, dan kisah-kisah lain yang menyimpan analogi seperti rentannya jaring laba-laba, gugurnya seutas daun yang tak pernah luput dari pandangan sang Khalik, atau kebringasan osean yang membuat kaum kafir memohon kepada Tuhan. Penjabaran yang berhubungan dengan sejarah dan metafora tersebut dalam pandangan Kuntowijoyo dapat mengajak pembacanya tentang arche-type atau keadaan global yang terjadi pada masa itu (Badar 2020:54).

Al-Qur'an menyimpan banyak deskripsi pembelajaran tentang moral etika yang peristiwanya bisa saja terulang hingga kini, namun dengan lakon dan waktu yang berbeda. Mimpi/keinginan profetik seperti ini secara akurat dituturkan dalam Al-Qur'an dalam surah Ali Imran 3:110 "Kamu adalah umat terbaik yang dilahirkan untuk manusia, menyuruh kepada yang ma'ruf, dan mencegah kemungkaran, dan beriman kepada Allah". Pernyataan yang terkandung dalam ayat tersebut menyatakan bahwa umat Islam ialah pengikut terunggul yang tercipta untuk insan yang berdarmai melaksanakan amar ma'ruf nahi munkar, dalam rangka keberimanan kepada Yang Maha Kuasa. Titik poin semacam ini menandakan pada kenyataannya mandat Rasulullah utusan Allah yang kita teladani ialah humanisasi, liberalisasi, dan transendensi. Pembahasan dalam surat Ali Imron ayat 110 menjadi landasan atas terbentuknya suatu konsep, dalam sebuah karya tulis terdapat peta konsep seni Islam profetik yang digambarkan sebagai berikut (Kuntowijoyo 2019:9).

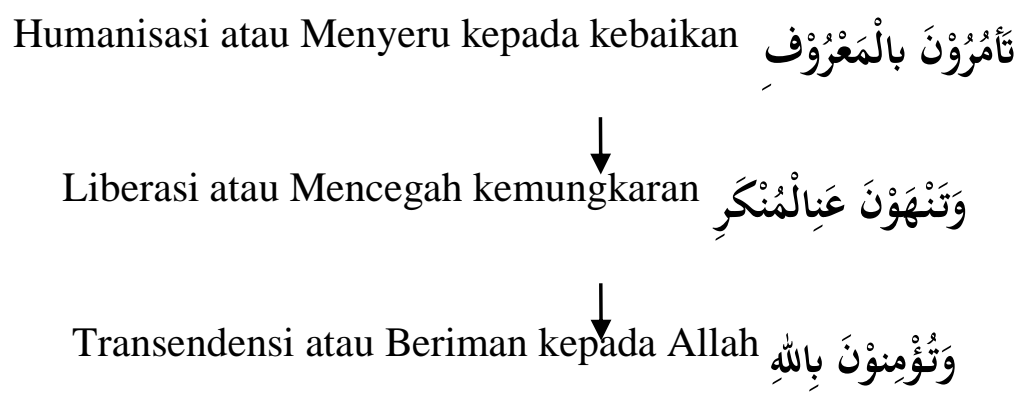

Kuntowijoyo berpendapat bahwa dalam penelitian pada ranah sosial berlandaskan ilmu sosial profetik hendaknya memprioritaskan kepada penyelesaian problematika umat dalam menghadapi masyarakat industri perkotaan, masyarakat pengetahuan, masyarakat global dan masyarakat yang abstrak (Kuntowijoyo 2007:105). Berikut dijelaskan satu persatu tentang ketiga poin yang menjadi konsep surat Ali Imran ayat 110.

1. Humanisasi atau menyeru kepada kebaikan

Istilah ini ialah tafsiran modern dari amar al-ma'ruf, yang dalam arti sesungguhnya adalah menganjurkan atau menyeru kepada kebaikan. Amar ma'ruf dimaksudkan untuk memberikan makna lebih kepada manusia untuk memanusiakan manusia agar mencapai suatu keadaan yang disebut fitrah. Berdasarkan pada pengertian ini konsep humanisasi yang disuarakan oleh Kuntowijoyo bersumber pada humanisme-teosentris.

2. Liberasi atau mencegah kemungkaran

Liberasi digunakan sebagai bahasa ilmu oleh Kuntowijoyo. Sedangkan dalam pandangan agama adalah nahi munkar, yang bermakna menghalangi atau mencekal segala tindakan kedurjanaan 
yang merugikan. Seperti contoh memperingati kawan mengonsumsi NAPZA, menghalangi bentrok sesama pelajar, menghempaskan kegiatan perjudian, memperingatkan perbuatan rentenir, dan lain sebagainya (Kuntowijoyo 1997:73). Nilai-nilai liberatif dalam ilmu sosial profetik dipahami dalam konteks sosial membebaskan manusia dari belenggu kekejaman, kemiskinan, pemerasan, dan penindasan (Arum 2018:185). Pada intinya liberasi merupakan upaya yang dilakukan untuk menghilangkan, menghapuskan, dan memberantas perbuatan tercela maupun akhlak buruk

3. Transendensi atau beriman kepada Allah

Kuntowijoyo menjelaskan bahwa unsur terpenting dalam ajaran keislaman ialah adanya makna tersirat ilmu sosial profetik pada transendensi dan juga secara serentak dijadikan landasan atas humanisasi dan liberasi sebagai dua komponen lainnya. Maka dari itu, (transendensi, humanisasi dan liberasi) ketignya tidak bisa dipisahkan satu dengan yang lain (Kuntowijoyo 2001:358). Kuntowijoyo dengan sastra profetiknya bermaksud melampaui keterbatasan akal pikiran manusia dan mencapai pengetahuan yang lebih. Oleh sebab itu, sastra profetik merujuk kepada pemahaman serta penafsiran kitab-kitab suci atas realitas. Sebagai sastra berdasarkan kitab-kitab suci, sastra profetik dimaksudkan sebagai sastra orang beriman (Jalalludin 2020:330). Transendensi yang diartikan pada bahasan kali ini ialah hasil verifikasi dari konsep teologi perihal Ketuhanan atau bisa juga disebut dalam istilah tu'minuna bi Allah (beriman kepada Allah).

Disamping itu, transendensi juga menjadi dasar humanisasi dan liberasi. Karena transendensi akan memberi arah ke mana dan untuk tujuan apa humanisasi dan liberasi dilakukan. Sebagai contoh, liberasi dalam konteks kemiskinan. Dalam menentukan pilihan antara bebaskan kemiskinan struktural yang dilakukan dengan cara menghancurkan para penguasa kekayaan dan memunculkan kaum miskin sebagai penguasa baru kekayaan. Seperti cita-cita Marxis yang memandang perjuangan kelas berarti menghancurkan kelas borjuis dan memunculkan diktator proletariat. Dengan liberasi yang menciptakan sistem ekonomi berkeadilan, tampaknya Islam lebih memilih yang terakhir. Dengan kata lain menghendaki transformasi struktural, dalam pengertian Islam selalu merekonstruksi struktur kesenjangan yang kerap kali terjadi pada masyarakat (Kuntowijoyo 2008:302).

Kuntowijoyo menjulukinya dengan pemahaman sintetik. Namun disayangkan ia tidak mengirnginnya dengan eksplanasi dengan cara eksplisit narasi yang dimaksud dengan pemahaman sintetik tersebut. Kuntowijoyo hanya mengatakan: “....merenungkan pesan-pesan moral Al-Qur'an dalam rangka meyintesiskan penghayatan dan pengalaman subjektif kita dengan ajaran-ajaran normatif'. Sesuai dengan kutipan tersebut, maka pendekatan sintetik ialah bentuk usaha mengaitkan wahyu dalam Al-Qur'an yang bermakna akhlak menuju subjektif supaya sisi lain etika individu menjadi lebih kuat. Akan tetapi pendekatan sintetik saja belum dapat dikatakan memadai sebab Alquran baru diterjemahkan pada level subjektif. Oleh karena itu, menerjemahkan Al-Qur'an pada tingkatan objektif utamanya berdasarkan fakta perubahan juga menjadi analisis kritik sebagai impian profetik Al-quran. Kuntowijoyo menawarkan strategi dalam rangka mentransformasi atau melakukan perubahan atas kesadaran subjektif menuju kesadaran objektif. Hal ini disebut sebagai pendekatan analitik (Kuntowijoyo 2007:14).

Kuntowijoyo menyinggung pendekatan sintetik-analitik terhadap konsep sebagai telaah lanjutan dari paradigma Al-Qur'an. Menurutnya mode of thought atau mode inquiry merupakan paradigma Al-quran berdasarkan visi Al-quran dengan realitas memahami dan jika diperlukan dirubah. Pada umumnya suatu paradigma Al-Qur'an yang menurutnya juga mengandung aspek 
ontologi, epistemologi, dan aksiologi. Cara pandang yang dipakai Kuntowijoyo dalam konteks paradigma Al-Qur'an nampaknya ditujukan pula untuk merangkai inisiatif revolusi ilmiah dalam Islam. Agar bisa sampai pada keadaan yang demikian, umat Islam harus merenungkan bagaimana menguatkan tradisi ilmiah yang memiliki kekhasan spesial yang menjadi pembeda terhadap karakter atau ciri khas ilmiah Barat. Kuntowijoyo terinspirasi oleh ayat ke-110 surat Ali Imran. Terdapat tiga kata kunci dalam ayat tersebut, yaitu ma'ruf, munkar, dan iman yang menurutnya bisa dijadikan inspirasi mengembangkan ilmu sosial profetik (Kuntowijoyo 2001:105).

Dengan mengembangkan teori-teori sosial alternatif yang dilandasi nilai-nilai keagamaan semacam ilmu sosial profetik, Kutowijoyo berharap umat Islam memiliki pegangan dalam menghadapi arus besar sejarah dengan tidak memberatkan salah satu. Misalnya terlalu bergantung kepada Tuhan, menganggap manusia itu pendosa, atau ingin melepaskan diri dan menganggap agama sebagai belenggu. Yang diinginkan agama Islam adalah mengintegrasikan semuanya dan mempertahankan keadilan yang ada.

\section{Kesimpulan}

Berdasarkan pembahasan penelitian yang telah dijabarkan, maka dapat disimpulkan bahwa sudah sepatutnya seorang muslim tidak lagi memaknai sesuatu dari teks menuju konteks. Gerakan intelektual harusnya berkembang menjadi konteks dan menuju teks. Tidak ada lagi islamisasi pengetahuan, harusnya berubah menjadi pengetahuan islam. Tujuannya adalah agar membuka cakrawala berfikir dengan realita kedepan yang selalu beubah-ubah (dinamis).

Struktur yang dikemukakan oleh Jean Peaget berbeda dengan yang dikemukakan oleh Kuntowijoyo. Jika yang dikemukakan oleh Jean tiga struktur tersebut berdiri sendiri, maka tidak dengan Kuntowijoyo, yang mengatakan bahwa ketiganya adalah satu-kesatuan dari unsur, yang mana unsurunsur tersebut tidak dapat di pisahkan.

Konsep Ilmu Sosial Profetik yang dikemukakan oleh Kuntowijoyo merupakan intisari dari Al-Qur'an Surat Ali Imran ayat 110, yang menyatakan terdapat tiga point penting, yaitu humanisasi, liberasi, dan transendensi. Ketiganya saling berkaitan menjadikan manusia sebagai khalifah (pemimpin) dimuka bumi, dapat melakukan suatu kegiatan apapun sesuai dengan keinginan dan kemampuan yang dimiliki, akan tetapi tidak melupakan bahwa semua itu akan kembali kepada Allah SWT karena pada hakikatnya manusia tetap sebagai hamba-Nya.

\section{Referensi}

Abidin, Muhammad Zainal. 2016. Paradigma Islam Dalam Pembangunan Ilmu Integralistik: Membaca Pemikiran Kuntowiijoyo. 1st ed. Banjarmasin: IAIN Antasari Press.

Agus, Bustanuddin. 2006. Agama Dalam Kehidupan Manusia: Pengantar Antropologi Agama. Jakarta.

Amstrong, Karen. 2001. Sejarah Tuhan. edited by Z. Am. Bandung: Mizan. 
Anon. n.d. "Kunto, Sang Budayawan, Sejarahwan, Dan Cendekiawan.” Retrieved June 20, 2021 (https://news.detik.com/berita/d-296819/kunto-sang-budayawan-sejarahwan-dancendekiawan).

Arifin, Syamsul. 2014. "Dimensi Profetisme Pengembangan Ilmu Sosial Dalam Islam Perspektif Kuntowijoyo." Tetrahedron Letters 55.

Arum, Khusni. 2018. "Pengembangan Pendidikan Agama Islam Berbasis Sosial Profetik ( Analisis Terhadap Pemikiran Kuntowijoyo ).” Millah: Jurnal Studi Islam 17(2):177-96.

Azizah, Nur, and Isaac Newton. 2018. "Hubungan Ilmu Dan Agama Dalam Prespektif Islam Telaah Pemikiran Kuntowijoyo.” 1(September):151-56.

Badar, M. Zainul. 2020. “Konsep Integrasi Antara Islam Dan Ilmu Telaah Pemikiran Kuntowijoyo.” 4(1):45-58.

Bagir, Zainal Abidin. Jarot Wahyudi dan Afnan Anshori. 2005. Integrasi Ilmu Dan Agama: Interpretasi Untuk Aksi. edited by Z. A. J. W. A. A. Bagir. Bandung: Mizan.

Fahmi, M. 2005. Islam Transendental: Menelusuri Jejak-Jejak Pemikiran Islam Kuntowijoyo. Yogyakarta: Pilar Religia.

Jalalludin, M. 2020. "Nilai Profetik Dalam Kumpulan Cerpen Pelajaran Pertama Bagi Calon Politisi Karya Kuntowijoyo Sebagai Bentuk Ekspresi Pendidikan Karakter Di Masa Pandemi." Prosiding Seminar Nasional Bahasa Dan ... (4):321-39.

Kahmad, Dadang. 2009. Sosiologi Agama. Bandung: Remaja Rosdakarya.

Kuntowijoyo. 1997. Identitas Politik Umat Islam. Bandung: Mizan.

Kuntowijoyo. 2001. Muslim Tanpa Masjid; Esai-Esai Agama, Budaya Dan Politik Dalam Budaya Politik Struktuartisme Transendental. Bandung: Mizan.

Kuntowijoyo. 2007. Islam Sebagai Ilmu: Epistimologi, Metodologi, Dan Etika. Yogyakarta: Tiara Wacana.

Kuntowijoyo. 2008. Paradigma Islam Interpretasi Untuk Aksi. edited by A. Priyono. Bandung: Mizan.

Kuntowijoyo. 2017. "Dinamika Sejarah Umat Islam Indonesia - Google Books.” Retrieved June 23, 2021

(https://www.google.co.id/books/edition/Dinamika_Sejarah_Umat_Islam_Indonesia/MRCsD wAAQBAJ?hl=id \&gbpv=1\&dq=dinamika+sejarah+umat+islam+indonesia \&printsec=frontco ver).

Kuntowijoyo. 2018. "Muslim Tanpa Masjid - Google Books." Retrieved June 21, 2021 (https://www.google.co.id/books/edition/Muslim_tanpa_Masjid/4J6sDwAAQBAJ?hl=id\&gb $\mathrm{pv}=1 \& \mathrm{dq}=$ muslim+tanpa + masjid $\&$ printsec $=$ frontcover $)$.

Kuntowijoyo. 2019. Maklumat Sastra Profetik. edited by A. N. S. P. Wahid. Yogyakarta: Diva Press. Peaget, Jean. 1995. Strukturalisme. edited by Hermoyo. Jakarta: Yayasan Obor Indonesia. 
Membaca Pemikiran Kuntowijoyo dalam Hubungan Ilmu dan Agama Perpektif Islam

Siti Qurrotul A'yuni, Radia Hijrawan

Suryo, Djoko. 2005. "Apresiasi Sejarah Kuntowijoyo." in Apresiasi Karya dan Pemikiran Kuntowijoyo. Yogyakarta.

Zulhelmi, Zulhelmi. 2018. "Konsep Khalifah Fil Ardhi Dalam Perspektif Filsafat (Kajian Eksistensi Manusia Sebagai Khalifah).” Intizar 24(1):37-54. doi: 10.19109/intizar.v24i1.1879. 